\title{
Establishing the Adoption of Electronic Word-of-Mouth through Consumers' Perceived Credibility
}

\author{
Yi-Wen Fan ${ }^{1}$, Yi-Feng Miao ${ }^{1}$, Yu-Hsien Fang ${ }^{1} \&$ Ruei-Yun Lin $^{1}$ \\ ${ }^{1}$ Department of Information Management, National Central University, Taoyuan, Taiwan (R.O.C.) \\ Correspondence: Yi-Wen Fan, Department of Information Management, National Central University, No.300, \\ Jhongda Rd., Jhongli City, Taoyuan County 32001, Taiwan (R.O.C.). E-mail: iwfan@mgt.ncu.edu.tw
}

Received: December 30, 2012

Accepted: January 21, 2013

Online Published: January 25, 2013

doi:10.5539/ibr.v6n3p58

URL: http://dx.doi.org/10.5539/ibr.v6n3p58

\begin{abstract}
In an online environment, consumers never touch the product and depend on electronic word-of-mouth (eWOM) to help them making purchase decision. The eWOM becomes one of the most influential channels of communication in the marketplace. This study aims to determine the importance of perceived credibility in an online consumer's decision-making process. In this empirical study, we verify that a consumer's perceived eWOM credibility positively influences his or her adoption of eWOM. We also found that source credibility, eWOM quantity, and eWOM quality significantly affect a consumer's perceived eWOM credibility.
\end{abstract}

Keywords: electronic word-of-mouth (eWOM), credibility

\section{Introduction}

Word-of-mouth (WOM) is one of the most influential channels of communication in the marketplace. The Internet provides numerous venues for consumers to share their views and experiences, and electronic WOM (eWOM) spreads at an unprecedented speed and at a much lower cost than traditional WOM (Li \& Zhan, 2011). Compared to general marketing communication tools, WOM is perceived to be more trustworthy and more relevant, and can reduce consumer resistance significantly because it originates from the experiences of other consumers (Bickart \& Schindler, 2001). With the popularization of the Internet, eWOM has begun to offer the promise of an emerging advertising discipline (Plummer, 2007).

How WOM changes consumer attitude toward purchasing decisions is worthy of investigation. WOM adoption is considered an effective measure for consumers' acceptance of communicator opinions (Li \& Zhan, 2011). Adoption refers to WOM persuasiveness, in addition to the degree that consumers are likely to rely on WOM in purchasing decisions (Duhan et al., 1997). Previous studies have also attempted to determine the factors that contribute to consumer WOM adoption because it is difficult to verify the authenticity and source of WOM, especially in an online environment (Cheung et al., 2009; McKnight \& Kacmar, 2006).

Trust is considered a vital factor affecting online consumer activities, such as the acceptance of others' advices (McKnight et al., 2002). Information credibility is an underlying dimension of trust, which is more appropriate for evaluating WOM communication; a consumer who believes online information to be credible has no reason to forego adoption (Cheung et al., 2009; Sallam \& Wahid, 2012). Compared with other attitude dimensions, how people construct online WOM credibility would be a significant topic for understanding the process of eWOM usage.

Studies on the impact of eWOM communication can be classified into two levels: market-level analysis and individual-level analysis (Lee \& Lee, 2009). At the market level of analysis, researchers have focused on market-level parameters such as product sales. Studies of this type have used objective panel data including the rating stars of a review, total number of reviews, the content length of each review, and the review content quality. At the individual level of analysis, researchers have postulated that eWOM is a process of personal influence in which communication between an eWOM sender and a receiver can change the receiver's attitude and purchasing decision.

Generally, elaboration likelihood model (ELM) provides a theoretical explanation of the message-processing route of a person's perception (Park et al., 2007). The ELM posits that people who are willing and able to process a message are more likely to process persuasive attempts by using the central route. In other words, they 
are more likely to generate their own thoughts in relation to arguments. However, people who lack motivation or ability are more likely to process information by using peripheral routes, or mental shortcuts, by focusing on non-content cues. Consumer involvement is associated with the motivation to process information, and expertise is associated with the ability to process information; these two factors are considered to represent consumer experience.

The objective of this study is to determine the factors that influence a consumer's perceived eWOM credibility and the importance of credibility in affecting a consumer's adoption of eWOM, including purchase intention. Theoretically, this study provides a viewpoint to clarify the impact of eWOM adoption in the purchase decision-making process and the important predictors of eWOM adoption. In practical terms, this study offers evidence that eWOM plays a significant role in consumer decision making. Thus, firms should not only focus on advisement creation, but also pay attention to consumer opinions.

\section{Literature Review and Research Hypotheses}

\subsection{Credibility and eWOM Adoption}

Wathen and Burkell (2002) indicated that source credibility is a key factor in assisting a consumer to judge online information. The first task for an online consumer is to rate the credibility of the medium itself, based on its surface characteristics. If a Web site presents a reliable interface, is well-designed, and has effective visuals, it attracts the consumer to remain on the site and continue using it. The second task involves rating the source regarding the message content because source credibility is fairly consistent with trustworthiness and expertise. The third aspect of the process involves assessing the interaction of the message presentation and the content with the consumer's cognitive state. This is determined from the consumer's experience and acknowledgment.

In an online environment, consumers rarely touch the product or recognize the eWOM sender. Source credibility is a vital predictor in the early stage when a consumer is choosing a Web site, and it contributes to the perceived credibility of messages on the site (Dabholkar, 2006; Dou et al., 2012). Consumer-perceived credibility of eWOM is defined as the extent to which one perceives a recommendation or review as believable, true, or factual (Cheung et al., 2009). Awad and Ragowsky (2008) suggested that perceived credibility is a prime determinant in a consumer's decision-making process, and reduces uncertainty in both social and business interactions. Therefore, we provide the following hypothesis:

\section{H1: Higher source credibility positively affects the perceived credibility of eWOM in consumers.}

Adopting eWOM is a psychological action that affects online consumers through social norms in an online environment. Sussman and Siegel (2003) indicated that a consumer who perceives a review to be credible has more confidence in adopting eWOM and using it to make purchase decisions. Perceived eWOM credibility refers to the judgments made by a message recipient concerning the believability of online reviews (Hong and Park, 2012). Researchers have also provided empirical evidence that if consumers perceive higher eWOM credibility, the likelihood of eWOM adoption rises (Cheung et al., 2009, Fan \& Miao, 2012, Lee \& Koo, 2012). We therefore formulate the following hypothesis:

\section{H2: Higher perceived eWOM credibility in consumers positively affects their adoption of eWOM.}

\section{2 eWOM Quantity and eWOM Quality}

When a consumer searches for online reviews, the quantity of eWOM makes the reviews more observable (Cheung \& Thadani, 2010); that is, the volume of eWOM represents the popularity of a product. Reading numerous reviews by others could reduce consumer anxiety when making a purchase decision because consumers reason that many others have also purchased the product (Chatterjee, 2001). Some empirical studies (Park et al., 2007; Sher \& Lee 2009) provided evidence that eWOM quantity positively influences the consumer-perceived credibility of eWOM. Therefore, we propose the following hypothesis:

\section{H3: A higher quantity of eWOM positively affects the perceived eWOM credibility of consumers.}

The quality of eWOM is another vital factor that is usually discussed with quantity. Once the eWOM on the site gains consumer attention, consumers begin to judge whether the review is worth reading. Information quality was proven early as a significant predictor of the success of an information system (DeLone \& McLean, 1992). Consumers care about the correctness and usefulness of eWOM, and good content quality increases their willingness to trust eWOM (Awad \& Ragowsky, 2008). Park, Lee, and Ham (2007) indicated that high-quality and the quantity of eWOM enhance persuasiveness. Therefore, we propose the following hypothesis:

H4: Higher-quality eWOM positively affects perceived eWOM credibility in consumers. 


\subsection{Elaboration Likelihood Model}

The ELM explains why people prefer to refer to others' opinions when making a purchase decision (Park et al., 2007; Li, 2012). People who are willing and able to process a message are more likely to process persuasive attempts using the central route. Otherwise, people who lack motivation or ability are more likely to process information using peripheral routes to consult the advice of others. In the ELM, involvement is associated with the motivation to process information, and expertise is associated with the ability to process information (Petty et al., 1983).

Park and Kim (2008) found that customers with high expertise are able to evaluate information according to experience and knowledge. Similarly, Bansal and Voyer (2000) indicated that consumers with higher expertise have more confidence in making purchase decisions and refer less to others' opinions. Therefore, we predicted that customer expertise affects the perceived credibility of eWOM, and proposed the following hypothesis:

\section{H5: Higher expertise in customers negatively affects their perceived eWOM credibility.}

Another issue with the ELM is involvement. Celsi and Olson (1988) indicated that involvement can be situational or enduring. Situational involvement is a temporary elevation of relevance regarding the objective product during the purchase decision-making process. We used situational involvement as a predictor in this study. Consumers with higher involvement have more motivation to understand products and are more likely to read others' opinions to gather more information. Therefore, we proposed the following hypothesis:

\section{H6: Higher involvement of consumers positively affects their perceived eWOM credibility.}

Figure 1 shows the research model used in this study.

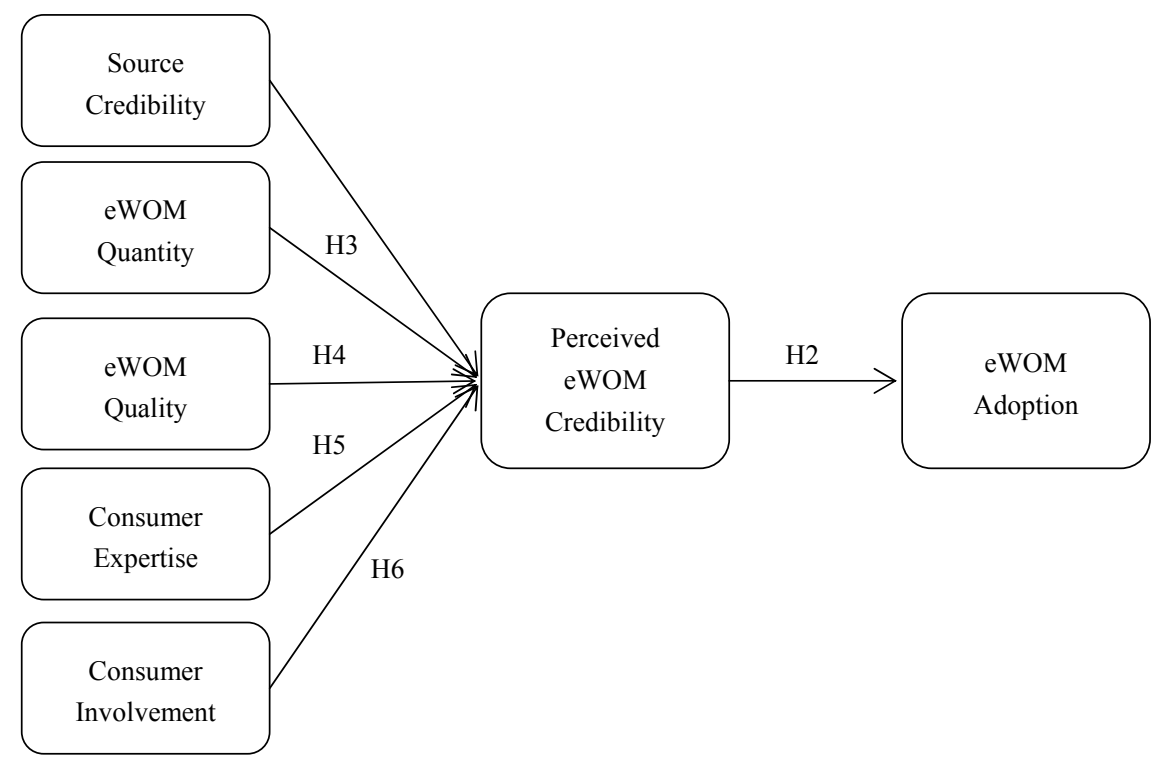

Figure 1. Research model

\section{Research Method}

Park and Lee (2009) indicated that eWOM has more impact on experience goods than search goods. This is because consumers cannot usually judge the attributes of an experience good before they purchase and use it (Huang et al., 2009). Additionally, consumers only gather information from product images and descriptions, especially in an online environment. Therefore, consumers must be aware of product reviews written by other consumers. For this study, we selected cosmetic products as an instrument to examine how eWOM influences a consumer's decision-making process.

We conducted an experiment that manipulates eWOM quantity and quality, thus resulting in a $2 \times 2$ (high quality vs. low quality, high quantity vs. low quantity) factorial designs. We defined high-quantity eWOM as eight reviews and low-quantity eWOM as four reviews, in accordance with the suggestion made by Park and Kim (2008). High-quality eWOM was defined as the provision of a pragmatic description about product attributes, whereas low-quality eWOM was defined as providing more emotional descriptions.

An initial structured questionnaire was developed based on a review of the relevant literature. We adopted 
eWOM-quantity items from Park, Lee, and Ham (2007), eWOM-quality items from Park and Kim (2008), source credibility and consumer expertise from Gefen and Straub (2004), consumer involvement from Premazzi et al. (2010), and perceived eWOM credibility and eWOM adoption from Cheung et al. (2009). All items were measured on a 5-point scale.

Subjects were randomly assigned to treatment conditions. Forty-six online shoppers participated in the pretest. Confirmatory factor analysis (CFA) was performed to establish reliability and validity. Cronbach's $\alpha$ of the indicators ranged from 0.821 to 0.917 , which is higher than the acceptance reliability coefficient level of 0.7 suggested by Nunnally (1978). Therefore, the questions used for this study were reliable. Regarding validity, the factor loadings belonging to each construct after analysis showed the standardized beta coefficients exceeding the required convergent validity score of 0.5 .

A total of 443 responses were collected, of which 435 were usable; 134 were in paper form, written by college and graduate students, and the remaining 301 were submitted by online users. The survey was posted on public cosmetic-related forums of a bulletin board system (BBS; telent://ptt.cc) and forwarded using Facebook to collect the experiences of eWOM users. Cronbach's $\alpha$ of the indicators ranged from 0.827 to 0.963 , and the factor loadings belonging to each construct showed significant standardized beta coefficients that were over 0.6. Table 1 shows the descriptive statistics, Table 2 shows the discriminant validity of this study, and Table 3 shows the CFA results.

Table 1. Sample characteristics

\begin{tabular}{lll}
\hline & Gender & \\
\cline { 2 - 3 } Male & Frequency & Percentage \\
Female & 156 & 35.9 \\
Total & 279 & 64.1 \\
& 435 & 100 \\
\hline Below 20 & Age & \\
\cline { 2 - 3 } $21-30$ & Frequency & Percentage \\
$31-40$ & 34 & 7.8 \\
$41-50$ & 367 & 84.4 \\
$51-60$ & 30 & 6.9 \\
61 and over & 3 & 0.7 \\
Total & 1 & 0.2 \\
& 0 & 0.0 \\
\hline
\end{tabular}

Table 2. Discriminate validity

\begin{tabular}{|c|c|c|c|c|c|c|c|c|c|}
\hline & AVE & $\mathrm{CR}$ & $\begin{array}{l}\text { Source } \\
\text { Credibility } \\
\text { (1) }\end{array}$ & $\begin{array}{l}\text { eWOM } \\
\text { Quantity } \\
\text { (2) }\end{array}$ & $\begin{array}{l}\text { eWOM } \\
\text { Quality } \\
(3)\end{array}$ & $\begin{array}{l}\text { Consumer } \\
\text { Expertise } \\
(4) \\
\end{array}$ & $\begin{array}{l}\text { Consumer } \\
\text { Involvement } \\
(5)\end{array}$ & $\begin{array}{l}\text { Perceived eWOM } \\
\text { Credibility } \\
(6)\end{array}$ & $\begin{array}{l}\text { eWOM } \\
\text { Adoption } \\
(7) \\
\end{array}$ \\
\hline (1) & 0.566 & 0.886 & 0.753 & & & & & & \\
\hline (2) & 0.852 & 0.920 & 0.438 & 0.923 & & & & & \\
\hline (3) & 0.614 & 0.905 & 0.535 & 0.570 & 0.783 & & & & \\
\hline (4) & 0.819 & 0.948 & 0.466 & 0.238 & 0.201 & 0.905 & & & \\
\hline (5) & 0.843 & 0.970 & 0.340 & 0.238 & 0.176 & 0.768 & 0.918 & & \\
\hline (6) & 0.819 & 0.931 & 0.583 & 0.543 & 0.695 & 0.273 & 0.245 & 0.905 & \\
\hline (7) & 0.682 & 0.915 & 0.546 & 0.593 & 0.716 & 0.282 & 0.293 & 0.681 & 0.826 \\
\hline Mean & N/A & N/A & 3.125 & 3.368 & 3.578 & 3.407 & 3.806 & 3.337 & 3.812 \\
\hline S.D. & N/A & N/A & 0.928 & 0.845 & 0.845 & 0.963 & 0.827 & 0.889 & 0.884 \\
\hline
\end{tabular}

\section{Results}

\subsection{Manipulation Checks}

The subject responses on the two items that were designed to check consumer perceptions of eWOM quantity were averaged. ANOVA was conducted, which indicated the presence of the main effect of review quantity [F(1, $433)=5.202, p<.05]$. Subjects in the eight-review condition perceived the review quantity to be greater, compared to subjects in the four-review condition $(\mathrm{M}=3.90$ and 3.72). Thus, the review quantity was 
manipulated successfully.

Subject responses to the manipulation checks on review quality were also examined. These were averaged for ANOVA. The results showed that subjects in the high-quality review condition had a greater perception of review quality than those in the low-quality review condition $[\mathrm{F}(1,433)=10.826, p<.001, \mathrm{M}=3.675$ and 3.473]. Therefore, the review quality was also successfully manipulated. Table 4 shows the ANOVA test of this study.

Table 3. CFA results

\begin{tabular}{|c|c|c|c|c|c|}
\hline Variables & Items & Factor loadings & Mean & S.D. & Cronbach's $\alpha$ \\
\hline \multirow[t]{6}{*}{ Source credibility } & $\mathrm{sc} 1$ & 0.672 & 3.368 & 0.623 & 0.845 \\
\hline & $\mathrm{sc} 2$ & 0.800 & & & \\
\hline & $\operatorname{sc} 3$ & 0.830 & & & \\
\hline & $\operatorname{sc} 4$ & 0.660 & & & \\
\hline & $\operatorname{sc} 5$ & 0.812 & & & \\
\hline & sc6 & 0.724 & & & \\
\hline \multirow[t]{2}{*}{ eWOM quantity } & qa1 & 0.928 & 3.806 & 0.826 & 0.827 \\
\hline & $\mathrm{qa} 2$ & 0.919 & & & \\
\hline \multirow[t]{6}{*}{ eWOM quality } & qu1 & 0.734 & 3.578 & 0.644 & 0.874 \\
\hline & qu2 & 0.800 & & & \\
\hline & qu3 & 0.753 & & & \\
\hline & qu4 & 0.759 & & & \\
\hline & qu5 & 0.794 & & & \\
\hline & qu6 & 0.854 & & & \\
\hline \multirow[t]{4}{*}{ Consumer expertise } & ex1 & 0.901 & 3.125 & 1.067 & 0.928 \\
\hline & ex2 & 0.850 & & & \\
\hline & ex3 & 0.920 & & & \\
\hline & ex4 & 0.946 & & & \\
\hline \multirow[t]{6}{*}{ Consumer involvement } & iv1 & 0.912 & 3.407 & 1.041 & 0.963 \\
\hline & iv2 & 0.931 & & & \\
\hline & iv3 & 0.932 & & & \\
\hline & iv4 & 0.941 & & & \\
\hline & iv5 & 0.890 & & & \\
\hline & iv6 & 0.901 & & & \\
\hline \multirow[t]{3}{*}{ Perceived eWOM credibility } & pec1 & 0.902 & 3.337 & 0.705 & 0.889 \\
\hline & pec2 & 0.897 & & & \\
\hline & pec3 & 0.915 & & & \\
\hline \multirow[t]{5}{*}{ eWOM adoption } & ad1 & 0.828 & 3.812 & 0.671 & 0.884 \\
\hline & $\mathrm{ad} 2$ & 0.752 & & & \\
\hline & $\mathrm{ad} 3$ & 0.837 & & & \\
\hline & ad4 & 0.881 & & & \\
\hline & ad5 & 0.872 & & & \\
\hline
\end{tabular}

Table 4. ANOVA test

\begin{tabular}{lllllll}
\hline Depend variable & Source & DF & Sum of squares & Mean squares & F ratio & F probability \\
\hline eWOM Quantity & Between & 1 & 3.512 & 3.512 & 5.202 & $0.023^{*}$ \\
& Within & 433 & 292.323 & 0.675 & & \\
& Total & 434 & 295.836 & & & \\
& Between & 1 & 4.931 & 4.931 & 0.826 & $0.001^{* *}$ \\
& Within & 433 & 175.618 & 0.406 & \\
& Total & 434 & 180.009 & & & \\
& & & & &
\end{tabular}

\subsection{Hypothesis Testing}

We used smartPLS for structure equation modeling (SEM) analysis. The full model $(n=435)$ is shown in Fig. 2. 
The research model shows that source credibility $(\beta=0.26, p<.000)$, eWOM quantity $(\beta=0.16, p<.001)$, and eWOM quality $(\beta=0.46, p<.000)$ all have a significant influence on consumer-perceived eWOM credibility, supporting H1, H3, and H4. Perceived eWOM credibility was shown to have a significant positive effect on eWOM adoption ( $\beta=0.68, p<.000$ ), supporting H2. Finally, consumer expertise and involvement do not have a significant effect on consumer-perceived eWOM credibility $(\beta=-0.02, p<.343 ; \beta=-0.05, p<.996)$; thus, H5 and $\mathrm{H} 6$ were not supported.

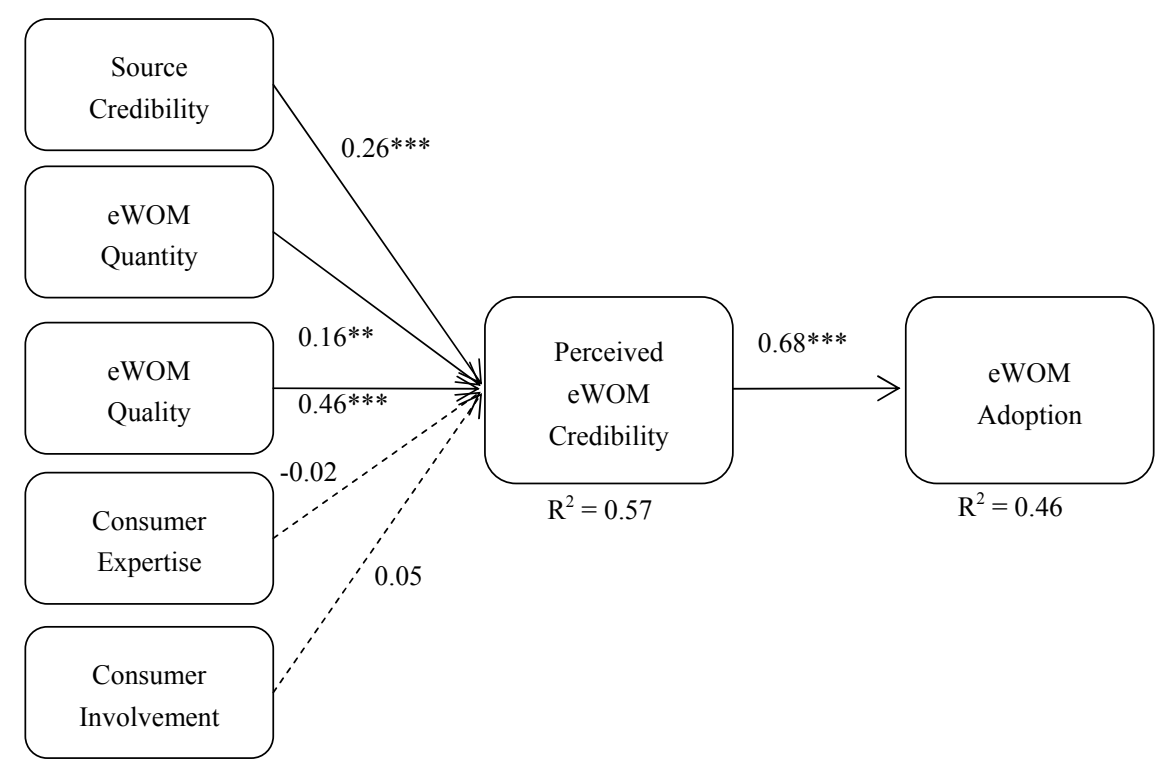

Figure 2. Hypothesis testing

Notes: $\mathrm{n}=435 ; * p<.05, * * p<.01, * * * p<.001$.

\section{Conclusion}

For this study, we focused on how perceived eWOM credibility in consumers influenced their eWOM adoption and the predictive factors of perceived eWOM credibility. Perceived eWOM credibility significantly affects eWOM adoption in consumers $\left(\beta=0.68, \mathrm{R}^{2}=0.46\right)$. Consumer adoption of eWOM represents how eWOM changes their attitude toward products, and may help them make purchase decisions. The survey results showed that constructing consumer credibility in an online environment is the most important aspect. Trust and credibility have generally been discussed in electronic commerce research, and are thought to be indispensable for predicting the activity of online consumers (Gefen \& Straub, 2004; Awad \& Ragowsky, 2008; Cheung et al., 2009; Fan \& Miao, 2012).

The quality of eWOM is the most significant factor, positively affecting the perceived credibility of consumers $(\beta=0.46, p<.001)$. Reviews that are pragmatic and persuasive, with a sufficient number of argumentative points based on factual information about the product, increase consumer confidence in referring to eWOM. In addition, in an online environment, consumers difficultly confirm the origin of the eWOM and the identity of the source. Source credibility measures the trustworthiness of the eWOM source, including the reviewer's expertise and the reputation of the vendor. This research provides evidence that source credibility also positively influences the perceived credibility of consumers $(\beta=0.26, p<.001)$.

The quantity of eWOM has a positive influence on the perceived credibility of consumers $(\beta=0.16, p<.01)$. The number of reviews is attracting consumer attention, and the consistency of numerous eWOM enhances eWOM reliability. Finally, although consumer expertise and involvement have no significant effect on perceived eWOM credibility, but the previous study offered a sight that consumer expertise reduces their perceived credibility of eWOM because they prefer making decisions on their own, and consumers who have higher involvement are willing to consider discussions and adopt others' opinions (Fan \& Miao, 2012). Some researchers have suggested that a consumer's involvement might be a moderator of perceived eWOM credibility (Park et al., 2007; Petty et al., 1983).

Our results have implications for the nature of eWOM credibility building. The decision-making process of consumers is influenced by the information content received. This study shows that specific aspects of informational influence, such as source credibility, eWOM quality, and eWOM quantity, can be highly influential 
on consumers' perceived eWOM credibility. A high level of eWOM credibility enhances a consumer's desire for eWOM adoption regarding the online recommendation, and attracts repeat visits to other consumers' recommendations. Furthermore, eWOM credibility also raises the overall value of the reviews provided, which benefits consumers who refer to the reviews. This study presents a model that provides firms which concerns online consumer reviews with strong instructional insight. We sought to determine the perceived credibility of consumers to make eWOM messages more useful. If the eWOM message is effective in a consumer's purchase decision-making process, then firms should focus more on maintaining their reputation and satisfying consumers.

\section{Limitation}

The main limitation of this study is that, although five factors were selected as the predictors of consumers' perceived eWOM credibility, only three were shown to have a significant influence. This might be because consumers usually notice the information content more, and ignore normative attributes. Cheung et al. (2009) indicated that a consumer's perceived credibility is influenced by informational and normative factors. Other possible factors that help construct perceived eWOM credibility and eWOM adoption exist, such as recommendation consistency and recommendation rating.

\section{References}

Awad, N. F., \& Ragowsky, A. (2008). Establishing trust in electronic commerce though online word of mouth: An examination across genders. Journal of Management Information Systems, 24(2), 101-121. http://dx.doi.org/10.2753/MIS0742-1222240404

Bansal, H. S., \& Voyer, P. A. (2000). Word-of-mouth processes within a services purchase decision context. Journal of Service Research, 3(2), 166-177. http://dx.doi.org/10.1177/109467050032005

Bickart, B., \& Schindler, R. M. (2001). Internet forums as influential sources of consumer information. Journal of Interactive Marketing, 15(3), 31-40. http://dx.doi.org/10.1002/dir.1014

Celsi, R., \& Olson, J. (1988). The role of involvement in attention and comprehension processes. Journal of Consumer Research, 15(2), 210-224. http://dx.doi.org/10.1086/209158

Chatterjee, P. (2001). Online reviews: Do consumers use them? Advances in Consumer Research, 28(1), 129-133.

Cheung, C. M. K., \& Thadani, D. R. (2010). The effectiveness of electronic word-of-mouth communication: A literature analysis. Proceedings of the 23rd Bled eConference eTrust: Implications for the Individual, Enterprises and Society.

Cheung, M., Luo, C., Sia, C., \& Chen, H. (2009). Credibility of electronic word-of-mouth: Informational and normative determinants of on-line consumer recommendations. International Journal of Electronic Commerce, 13(4), 9-38. http://dx.doi.org/10.2753/JEC1086-4415130402

Dabholkar, P. A. (2006). Factors influencing consumer choice of a "rating web site": An experimental investigation of an online interactive decision aid. Journal of Marketing Theory and Practice, 14(4), 259-273. http://dx.doi.org/10.2753/MTP1069-6679140401

DeLone, W. H., \& McLean, E. R. (1992). Information systems success: The quest for the dependent variable. Information Systems Research, 3(1), 60-95. http://dx.doi.org/10.1287/isre.3.1.60

Dou, X., Walden, J. A., Lee, S., \& Lee, J. Y. (2012). Does source matter? Examining source effects in online product reviews. Computers in Human Behavior, 28(5), 1555-1563. http://dx.doi.org/10.1016/j.chb.2012.03.015

Duhan, D. F., Johnson, S. D., Wilcox, J. B., \& Harrell, G. D. (1997). Influences on consumer use of word-of-mouth recommendation sources. Journal of the Academy of Marketing Science, 25(4), 283-295. http://dx.doi.org/10.1177/0092070397254001

Fan, Y. W., \& Miao, Y. F. (2012). Effect of electronic word-of-mouth on consumer purchase intention: The perspective of gender differences. International Journal of Electronic Business Management, 10(3), 175-181.

Gefen, D., \& Straub, D. W. (2004). Consumer trust in B2C e-commerce and the importance of social experiments in e-products and e-services. Omega, 32(6), 407-424. http://dx.doi.org/10.1016/j.omega.2004.01.006

Hong, S., \& Park, H. S. (2012). Computer-mediated persuasion in online reviews: Statistical versus narrative 
evidence. Computers in Human Behavior, 28(3), 906-919. http://dx.doi.org/10.1016/j.chb.2011.12.011

Huang, P., Lurie, N. H., \& Mitra, S. (2009). Searching for experience on the web: An empirical examination of consumer behavior for search and experience goods. Journal of Marketing, 73(2), 55-69. http://dx.doi.org/10.1509/jmkg.73.2.55

Lee, K. T., \& Koo, D. M. (2012). Effects of attribute and valence of e-WOM on message adoption: Moderating roles of subjective knowledge and regulatory focus. Computers in Human Behavior, 28(5), 1974-1984. http://dx.doi.org/10.1016/j.chb.2012.05.018

Li, C. Y. (2013). Persuasive messages on information system acceptance: A theoretical extension of elaboration likelihood model and social influence theory. Computers in Human Behavior, 29(1), 264-275. http://dx.doi.org/10.1016/j.chb.2012.09.003

Li, J., \& Zhan, L. J. (2011). Online persuasion: How the written word drives WOM evidence from consumer-generated product reviews. Journal of Advertising Research, 51(1), 239-257. http://dx.doi.org/10.2501/JAR-51-1-239-257

McKnight, D. H., \& Kacmar, C. (2006). Factors of information credibility for an internet advice site. Proceedings of the 39th Hawaii International Conference on System Science.

McKnight, D. H., Choudhury, V., \& Kacmar, C. (2002). Developing and validating trust measures for e-commerce: An integrative typology. Information Systems Research, 13(3), 334-359. http://dx.doi.org/10.1287/isre.13.3.334.81

Nunnally, J. C. (1978). Psychometric Theory. New York: McGraw-Hill.

Park, C., \& Lee, T. M. (2009). Information direction, website reputation and eWOM effect: A moderating role of product type. Journal of Business Research, 62(1), 61-67. http://dx.doi.org/10.1016/j.jbusres.2007.11.017

Park, D., \& Kim, S. (2008). The effects of consumer knowledge on message processing of electronic word-of-mouth via online consumer reviews. Electronic Commerce Research and Applications, 7(4), 399-410. http://dx.doi.org/10.1016/j.elerap.2007.12.001

Park, D., Lee, J., \& Ham, I. (2007). The effect of on-line consumer reviews on consumer purchasing intention: The moderating role of involvement. International Journal of Electronic Commerce, 11(4), 125-148. http://dx.doi.org/10.2753/JEC1086-4415110405

Petty, R. E., Cacioppo, J. T., \& Schumann, D. (1983). Central and peripheral routes to advertising effectiveness: The moderating role of involvement. Journal of Consumer Research, 10(2), 135-146. http://dx.doi.org/10.1086/208954

Plummer, J. T. (2007). Word of mouth: A new advertising discipline? Journal of Advertising Research, 47(4), 385-386. http://dx.doi.org/10.2501/S0021849907070390

Premazzi, K., Castaldo, S., Grosso, M., Raman, P., Brudvig, S., \& Hofacker, C. F. (2010). Customer information sharing with e-vendors: The roles of incentives and trust. International Journal of Electronic Commerce, 14(3), 63-91. http://dx.doi.org/10.2753/JEC1086-4415140304

Sallam, M. A. A., \& Wahid, N. A. (2012). Endorser credibility effects on Yemeni male consumer's attitudes towards advertising, brand attitude and purchase intention: The mediating role of attitude toward brand. International Business Research, 5(4), 55-66. http://dx.doi.org/10.5539/ibr.v5n4p55

Sher, P., \& Lee, S. (2009) Consumer skepticism and online reviews: An elaboration likelihood model perspective. Social Behavior and Personality, 37(1), 137-143. http://dx.doi.org/10.2224/sbp.2009.37.1.137

Sussman, S. W., \& Siegel, W. S. (2003). Informational influence in organizations: An integrated approach to knowledge adoption inform. Systems Research, 14(1), 47-65.

Wathen, C. N., \& Burkell, J. (2002). Believe it or not: Factors influencing credibility on the web. Journal of the American Society for Information Science \& Technology, 53(2), 134-144. http://dx.doi.org/10.1002/asi.10016 